Volume 3, Number 1, 2017

\title{
Investigations on the Innovation Model of Exergy Effectiveness of Air Conditioning System for Operating Cleanrooms
}

\author{
Dmytro Harasym, Volodymyr Labay* \\ Lviv Polytechnic National University, 12 S. Bandery St., Lviv, 79013, Ukraine
}

Received: March 12, 2017. Revised: April 06, 2017. Accepted: April 14, 2017.

(C) 2017 The Authors. Published by Lviv Polytechnic National University.

\begin{abstract}
The issue of fuel and energy saving is a top priority for energy technological systems (ETS) such as air conditioning systems (ACS). Thus, reduction of energy consumption for ACS requires optimization of these systems which can be obtained on the basis of the exergy analysis. This analysis takes into account not only the quantity of the energy being consumed but also its quality. By taking into account the exergy during calculation of balances and various characteristics of ETC (including ACS) the scientific and engineering problems can be solved in a simple and easily understandable way. Frequent mistakes caused by ignoring the quality of transformations can be avoided. Innovation mathematical research model of the existing central straight flow air conditioning system for operating cleanrooms with the aim of computer estimation of its energy effectiveness by virtue of exergetic output-input ratio depending on different factors, which have influence on its operation, is presented in this article. The dependence of exergetic output-input ratio $\eta_{e}$ of the existing air conditioning system on temperature difference between the inside and the supplied air $\Delta t_{S}=t_{i n}-t_{S}$ was defined based on this model.
\end{abstract}

Keywords: exergy balance; air conditioning systems; cleanrooms; exergy efficiency.

\section{Introduction}

Nowadays, during the exploitation of energy technological systems (ETS), which include air conditioning systems (ACS), to ensure carrying out a certain technology, the question of economy of fuel and energy resources is of prime importance. That's why the question about ETS, that can organically combine and complement the requirements of technology and power engineering, is raised now.

In modern technologies, which are related to energy transformation, namely in air conditioning systems, important places are occupied by equipment and processes, the objective estimation of value of its energy perfection can be defined only on the basis of its thermodynamic analysis. The simplest method of thermodynamic analysis is energy one based on the law of energy conservation. It allows us to estimate absolute and relative energy losses, to reveal equipment and processes with the highest losses. However, this method equates all kinds of energy, thermal energy in particular, that is wrong from the position of the second law of thermodynamics, because any kind of energy can be completely converted into the thermal one, the reverse process at the same time is accompanied by the unavoidable losses.

Under the influence of these requirements, the exergy method of analysis has been designed in the last decades [6-10]. This method was described in the works of R. Clausisus, J. Gibbs, G. Guye, A. Stodola, Y. Shargut and R. Petela. Its main idea is to introduce, along with the common, fundamental concept of energy, the additional indicator - exergy, which allows considering the fact, that the energy depending on external conditions may have a different value for practical use.

\footnotetext{
*Corresponding author. Email address: wlabay@i.ua
}

This paper should be cited as: D. Harasym, V. Labay. Investigations on the Innovation Model of Exergy Effectiveness of Air Conditioning System for Operating Cleanrooms. Energy Eng. Control Syst., 2017, Vol. 3, No. 1, pp. 15 - 22. https://doi.org/10.23939/jeecs2017.01.015 
The calculations of balances and different characteristics of energy technological systems, air conditioning systems in particular, taking into account the exergy, enable us to solve many scientific and technical problems in the easiest and clearest way. They help to remove frequent errors that can be found and are associated with ignoring the qualitative side of transformation.

The feature of the central straight flow air conditioning system is that the starting substance, which is processed in it is the outside air, the parameters of which may vary as the temperature and the relative humidity (moisture content and specific enthalpy, relatively). As the result of the operation, the air conditioning system provides required temperature and humidity of supplied and indoor air depending on the parameters of outside air. Reduction in the cost of energy consumed by air conditioning systems dictates the need of its optimization, which can be fully achieved by virtue of exergetic analysis, that takes into account not only the quantity, but also the quality of energy spent $[7,8,11-14,16,18-20]$.

\section{Description of the object that is analyzed and of its innovation research model}

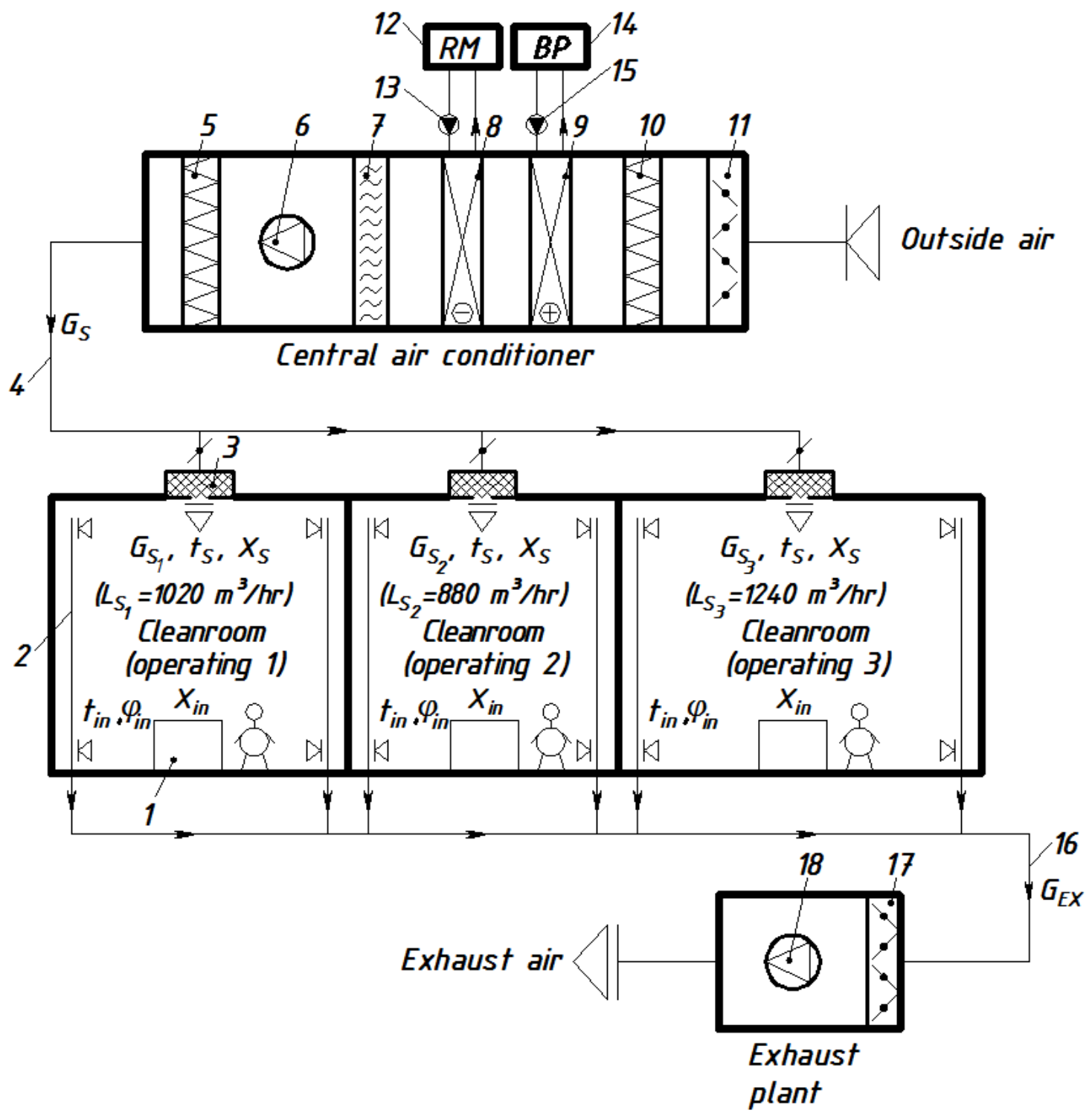

Fig.1. Basic scheme of the implemented central straight flow air conditioning system for operating cleanrooms: 1 - technological equipment; 2 - air exhaust channels in cleanrooms; 3 - filters of supplied air to the room; 4 - supplied air duct; 5 - filter of supplied air in a conditioner; 6 - fan unit of conditioner; 7 - drop catcher of conditioner; 8 - air cooler of conditioner; 9 - air heater of conditioner; 10 - filter of outside air in conditioner; 11 - valve of outdoor air in conditioner; 12 - refrigerating machine RM; 13 - pump of cold water of RM; 14 - boiler plant BP; 15 - pump of warm water; 16 - exhaust air duct; 17 - valve of exhaust air; 18 - fan unit of the exhaust plant 
Let's consider the central straight flow air conditioning system for operating cleanrooms implemented by the authors', which is shown in Fig. 1. The operation of the system depends on the dominant environmental conditions, i.e. on temperature and moisture content of the outdoor air. So, at a warm period of year outdoor air is taken via central conditioner through the valve 11 , is cleaned in the filter 10, then passes through the air heater 9 , is politropical cooled and drained in the air cooler 8, is separated in the drops catcher 7 and after that this air is supplied through the air supply filter of conditioner 5 and air supply filters 3 at the entrance of operating cleanrooms via the fan unit 6 . The exhaust air of the operating cleanrooms is removed from their top and lower zones via extraction system through its valve 17 by the extractor fan 18 .

Let's consider the work of this air conditioning system at a warm period of year, when temperature $t_{\text {in }}<t_{\text {out }}$. Figure 2 shows in a coordinate system $I, d$ the sequence of change of air parameters, which passes through the different equipment of the implemented central straight flow air conditioning system for operating cleanrooms at a warm period of year at different parameters of outdoor air. In the researches, mass productivity of the air conditioning system $G=4300 \mathrm{~kg} / \mathrm{g}$, that was counted by the necessary multiplicity of air exchange, parameters of outdoor air varied within: temperature $t_{\text {out }}=30-40^{\circ} \mathrm{C}$; relative humidity $\varphi_{\text {out }}=44-36 \%$ (in accordance, moisture content and specific enthalpy $d_{\text {out }}=11.7-16.8 \mathrm{~g} / \mathrm{kg} ; I_{\text {out }}=60.1-83.4 \mathrm{~kJ} / \mathrm{kg}$ ), barometric pressure $p_{\text {out }}=1010 \mathrm{hPA}$; parameters of indoor air, accordingly $-t_{\text {in }}=25-29^{\circ} \mathrm{C} ; \varphi_{\text {in }}=54-64 \%$ (in accordance, $d_{\text {in }}=10.8-16.3 \mathrm{~g} / \mathrm{kg} ; I_{\text {in }}=52.6-70.8$ $\mathrm{kJ} / \mathrm{kg}$ ); temperature difference between inside and supplied air depending on excess heat in the cleanroom and also on temperature of outdoor air $\Delta t_{\mathrm{S}}=t_{\text {in }}-t_{\mathrm{S}}=9.0-4.0^{\circ} \mathrm{C}$; slope coefficient of excess heat and moisture assimilation in the cleanroom by the supplied air via air conditioner $\varepsilon=27058-9711 \mathrm{~kJ} / \mathrm{kg}$; initial temperature of the coolant $(40 \%$ propylene glycol solution) for the air cooler $t_{\mathrm{w}_{\mathrm{I}}}=9.5-15.5^{\circ} \mathrm{C}$.

The sequences of changes, that occur with the moist air, which passes through the various equipment of the implemented air conditioning system, are shown in Fig. 2. Construction on the $I-d$-diagram was made in accordance with [11]. Parameters of air in the characteristic points of the process (Fig. 2) were determined by the adopted values of parameters for outdoor air and were calculated on the proposed mathematical model by the known analytical dependences for moist air.

Cold consumption for air treatment in the air cooler (cooling capacity of air cooler) at a warm period of the year was defined by the equation:

$$
Q_{C}=G_{S} \cdot\left(I_{O}-I_{S_{1}}\right) \times 0.278, \mathrm{~W},
$$

where $I_{\mathrm{O}}$ and $I_{\mathrm{S}_{1}}$ - specific enthalpy of air at the corresponding points of processes of change in the state of moist air in the implemented straight flow air condition system at a warm period of year on the $I$ - $d$ - diagram (Table 1), $\mathrm{kJ} / \mathrm{kg}$.

The aim of this work was to create innovation mathematical research model of the implemented central straight flow air conditioning system for operating cleanrooms with the aim of computer estimation of its energy effectiveness by virtue exergetic output-input ratio depending on different factors, which have influence on its work. Material, heat (energy) and exergy balances of the system were made up in this model, which took into account all the possible variants of its work in real conditions.

The concept of exergetic output-input ratio was used for the rational excellence assessment of the air conditioning system, which was defined as the ratio of air exergy increase in air conditioned premises $E_{\text {out }}$ to the exergy of air conditioning system transmission $E_{\text {in }}$, which was spent on maintaining the process $[6-10,12,13,15$ 20]:

$$
\eta_{e}=\frac{E_{\text {out }}}{E_{\text {in }}}
$$




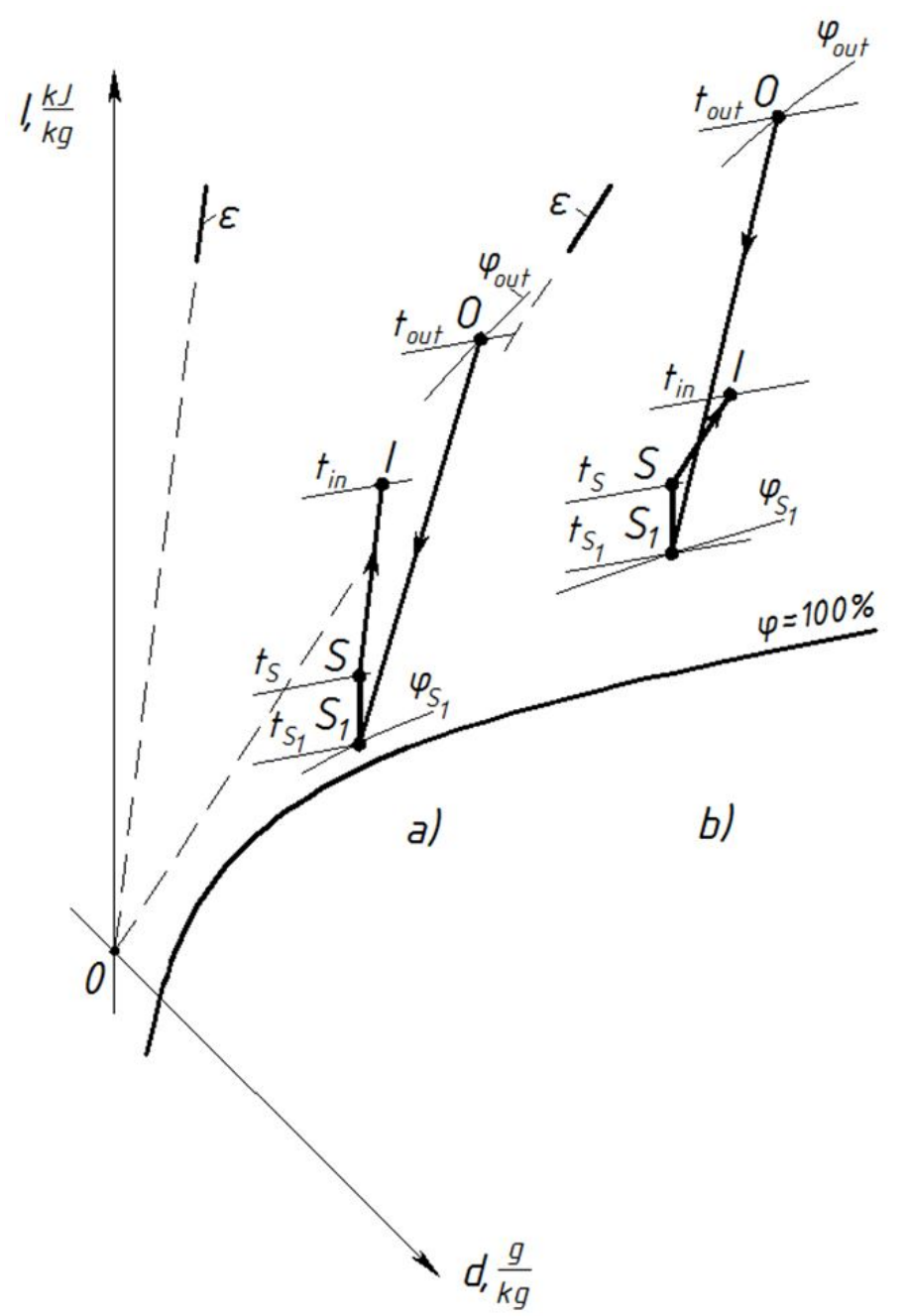

Fig. 2. The image of the process of changing the state of moist air in the implemented central straight flow air conditioning system in a warm period of year on the $I-d$-diagram: a) for conditions of the research $-t_{\text {out }}=30 ; 32^{\circ} \mathrm{C} ; t_{\text {in }}=25 ; 26^{\circ} \mathrm{C} ; \Delta t_{\mathrm{S}}=9 ; 7^{\circ} \mathrm{C}$; b) for conditions of the

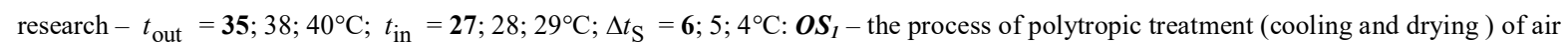
$G_{\text {out }}=G_{\mathrm{S}}$ in the air cooler; $\boldsymbol{S}_{\mathbf{1}} \boldsymbol{S}$ - the process of supplied air $G_{\mathrm{S}}$ heating by $1^{\circ} \mathrm{C}$ in a fan and duct; $\boldsymbol{S I}$ - the process of excess heat and moisture assimilation in a cleanroom by supplied air $G_{\mathrm{S}}$ via the conditioner

The exergetic output-input ratio, which characterizes the effectiveness of work of the implemented central straight flow air conditioning system for operating cleanrooms at a warm period of year, was defined by the equation:

$$
\eta_{\mathrm{e}}=\frac{E_{\text {out }}}{E_{\text {in }}}=\frac{\Delta E_{\mathrm{SI}}}{\Delta E_{\mathrm{OS}_{1}}+\Delta E_{\mathrm{S}_{1} \mathrm{~S}}+\Delta E_{\mathrm{SI}}+\Delta E_{\text {exh }}+N_{\text {use }}^{\text {sup.fan }}+N_{\text {use }}^{\text {exh.fan }}+N_{\text {use }}^{\mathrm{RM}}} .
$$

where $E_{\text {out }}=\Delta E_{\mathrm{SI}}=E_{\mathrm{S}}-E_{\mathrm{I}}$ - exergy reduction of conditioned air in the surgery operating cleanrooms (usefully used exergy), $\mathrm{W} ; E_{S}$ and $E_{I}$ - in accordance, exergy of supplied and indoor air in the cleanrooms, W; $\Delta E_{\mathrm{OS}_{1}}=E_{\mathrm{S}_{1}}-E_{\mathrm{O}}$ - increasing of exergy of air in the air cooler of conditioner, W; $E_{\mathrm{S}_{1}}$ i $E_{\mathrm{O}}$ - in accordance, exergy of air which is processed (outdoor air) at the exit and entrance of the air cooler of conditioner, $\mathrm{W} ; \Delta E_{S_{I} S}=E_{S_{I}}-E_{S}$ - exergy reduction of air during its transportation in the supplied ducts and fan of air conditioning system, $\mathrm{W} ; E_{\mathrm{S}_{1}}$ i $E_{\mathrm{S}}-$ in accordance, exergy of air at the entrance of supplied fan of conditioner and at the exit of supplied ducts to the cleanrooms, $\mathrm{W} ; \Delta E_{\mathrm{ex}}=E_{\mathrm{I}}-E_{\mathrm{O}}-$ exergy losses with exhaust conditioned air from the cleanrooms, $\mathrm{W} ; N_{\text {use }}^{\text {sup.fan }}-$ 
consumed power via the supplied fan of the conditioner, $\mathrm{W} ; N_{\text {use }}^{\text {ex.fan }}$ - consumed power via the fan of the exhaust plant, W; $N_{\text {use }}^{\mathrm{RM}}$ - consumed power via the refrigerating machine for the central conditioner, $\mathrm{W}$.

The values, included in the equation (3) for the determination of exergetic output-input ratio of implemented ACS at a warm period of year, were defined as follows:

$$
\Delta E_{S I}=G_{S} \cdot\left(e_{S}-e_{i n}\right) \times 0.278, \mathrm{~W},
$$

where $e_{\mathrm{S}}$ i $e_{\text {in }}-$ in accordance, specific exergy of supplied and indoor air in the cleanrooms (Table 1), $\mathrm{kJ} / \mathrm{kg}$;

$$
\Delta E_{O S_{I}}=G_{S} \cdot\left(e_{S 1}-e_{\text {out }}\right) \times 0.278, \mathrm{~W},
$$

where $e_{\text {out }}$ i $e_{\mathrm{S}_{1}}$ - in accordance, specific exergy of outdoor air and of cooled and drained air in the air cooler, (Table 1), kJ/kg;

$$
\Delta E_{S_{l} S}=G_{S} \cdot\left(e_{S 1}-e_{S}\right) \times 0.278, \mathrm{~W},
$$

where $e_{\mathrm{S}}-$ specific exergy at the exit of supplied ducts in the cleanrooms (Table 1), $\mathrm{kJ} / \mathrm{kg}$;

$$
\Delta E_{\text {exh }}=G_{S} \cdot\left(e_{\text {in }}-e_{\text {out }}\right) \times 0.278, \mathrm{~W} .
$$

Based on the mentioned equations, the exergetic output-input ratio $\eta_{e}$ for the implemented air conditioning system at a warm period of year was calculated and an appropriate conclusions were made.

Specific exergy of moist air was determined as follows.

Specific exergy of moist air at a certain points of the processes which characterize the work of the implemented central straight flow air conditioning system was determined by the following equations:

$$
e=e_{\mathrm{ph}}+e_{\mathrm{ch}}, \mathrm{kJ} / \mathrm{kg}
$$

where $e_{\mathrm{ph}}$ and $e_{\mathrm{ch}}-$ in accordance, specific physical and chemical exergy in relation to parameters of outdoor air (environment);

$$
e_{\mathrm{ph}}=\left(\bar{c}_{\mathrm{d} \text {. air }}+\bar{c}_{\mathrm{vap}} \cdot \frac{d}{1000}\right) \cdot\left(T-T_{0}-T_{0} \cdot \ln \frac{T}{T_{0}}\right), \mathrm{kJ} / \mathrm{kg},
$$

$\bar{c}_{\text {d.air }}=1.005 \mathrm{~kJ} /(\mathrm{kg} \cdot \mathrm{K})$ and $\bar{c}_{\text {vap }}=1.86 \mathrm{~kJ} /(\mathrm{kg} \cdot \mathrm{K})-$ in accordance, average specific heat capacity (at constant pressure) of dry air water vapor;

$T_{0}$ i $T$ - in accordance, absolute temperature of outdoor air (environment) and of air at a certain point of the process, $\mathrm{K}(273+t=T)$;

$$
e_{\mathrm{ch}}=T_{0} \cdot\left[\left(R_{\mathrm{d} \text {. air }}+R_{\text {vap }} \cdot \frac{d}{1000}\right) \cdot \ln \frac{622+d_{0}}{622+d}+R_{\text {vap }} \cdot \frac{d}{1000} \cdot \ln \frac{d}{d_{0}}\right], \mathrm{kJ} / \mathrm{kg}
$$

$R_{\text {d.air }}=0.287 \mathrm{~kJ} /(\mathrm{kg} \cdot \mathrm{K})$ i $R_{\text {vap }}=0.462 \mathrm{~kJ} /(\mathrm{kg} \cdot \mathrm{K})$ - in accordance, gas constant of dry air and of water vapor;

$d_{0}$ i $d$ - in accordance, moisture content of outdoor air (environment) and of air at a certain points of the process, $\mathrm{g} / \mathrm{kg}$. 
The results of calculations of specific exergy of moist air at a certain points of the processes, which characterize the work of the implemented central straight flow air conditioning system, are summarized in Table 1.

It should be noted that we didn't take into account exergy losses which are related to losses of aerodynamic pressure of air flow, which are minor and could be ignored, and also losses into environment. The parameters, which characterize the state of the air at all points of the processes for the given air conditioning system, are summarized in Table 1.

Table 1. Parameters of points, which describe the state of moist air during the work of the implemented air conditioning system

\begin{tabular}{|l|c|c|c|c|c|}
\hline $\begin{array}{c}\text { Points } \\
\text { on the } \\
I-d-\text { diagram }\end{array}$ & $\begin{array}{c}\text { Temperature } \\
t,{ }^{\circ} \mathrm{C}\end{array}$ & $\begin{array}{c}\text { Specific } \\
\text { enthalpy } \\
I, \mathrm{~kJ} / \mathrm{kg}\end{array}$ & $\begin{array}{c}\text { Moisture content } \\
d, \mathrm{~g} / \mathrm{kg}\end{array}$ & $\begin{array}{c}\text { Relative } \\
\text { humidity } \\
\varphi, \%\end{array}$ & $\begin{array}{c}\text { Specific } \\
\text { exergy } \\
e, \mathrm{~kJ} / \mathrm{kg}\end{array}$ \\
\hline \hline $\mathrm{O}$ & $30-40$ & $60.1-83.4$ & $11.7-16.8$ & $44-36$ & $0.0-0.0$ \\
\hline $\mathrm{S}_{1}$ & $15-24$ & $42.1-64.7$ & $10.5-15.8$ & $98-84$ & $0.4020-0.4421$ \\
\hline $\mathrm{S}$ & $16-25$ & $42.6-65.4$ & $10.5-15.8$ & $92-79$ & $0.3505-0.3882$ \\
\hline $\mathrm{I}$ & $25-29$ & $52.6-70.8$ & $10.8-16.3$ & $54-64$ & $0.0475-0.2059$ \\
\hline
\end{tabular}

\section{Results of the research work}

Substituting the received values by the research calculations in equation (3), we calculated the value of exergetic output-input ratio $\eta_{e}$ for the implemented air conditioning system depending on outdoor temperature conditions, namely: temperature $t_{\text {out }}$ and relative humidity $\varphi_{\text {out }}$ of outdoor air, and showed them in the form of dependence of exergetic output-input ratio on temperature difference between indoor and supplied air $\Delta t_{\mathrm{S}}$ at a Fig. 3 and on this basis were making conclusions.

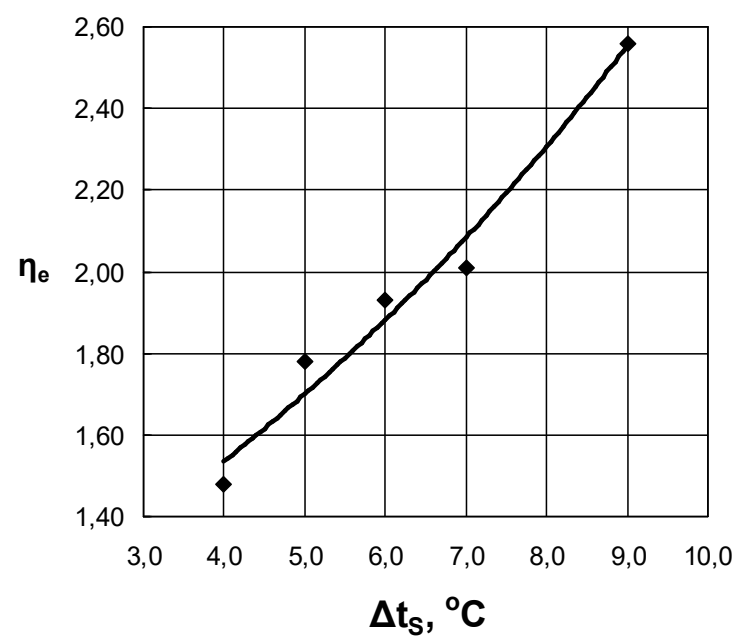

Fig. 3. The dependence of exergetic output-input ration $\eta_{e}$ of the implemented central straight flow air conditioning system for operating cleanrooms at a warm period of year on temperature difference between indoor and supplied air $\Delta t_{\mathrm{S}}:$ point $1-\Delta t_{\mathrm{S}}=4.0^{\circ} \mathrm{C}\left(t_{\text {out }}=40^{\circ} \mathrm{C}\right.$; $\left.\varphi_{\text {out }}=36 \% ; t_{\text {in }}=29^{\circ} \mathrm{C} ; \varphi_{\text {in }}=64 \% ; \varphi_{\mathrm{S}}=79 \%\right) ;$ point $2-5.0^{\circ} \mathrm{C}\left(38^{\circ} \mathrm{C} ; 38 \% ; 28^{\circ} \mathrm{C} ; 64 \% ; 84 \%\right) ;$ point $3-6.0^{\circ} \mathrm{C}\left(35^{\circ} \mathrm{C} ; 40 \% ; 27^{\circ} \mathrm{C} ; 60 \%\right.$; $84 \%)$; point $4-7.0^{\circ} \mathrm{C}\left(32{ }^{\circ} \mathrm{C} ; 42 \% ; 26^{\circ} \mathrm{C} ; 55 \% ; 82 \%\right)$; point $5-9.0^{\circ} \mathrm{C}\left(30^{\circ} \mathrm{C} ; 44 \% ; 25^{\circ} \mathrm{C} ; 54 \% ; 92 \%\right)$

Analyzing the obtained research data of a Fig. 3 the following conclusions can be reached. General increase in temperature difference between indoor and supplied air $\Delta t_{\mathrm{S}}$ from 4.0 to $9.0^{\circ} \mathrm{C}$, namely by 2.25 times, leads to a significant growth of exergetic output-input ratio $\eta_{e}$ from 1.48 to 2.56 , namely by 1.73 times or at $73 \%$. Therewith, the average speed of change of exergetic output-input ratio $\eta_{e}$ is $\Delta \eta_{\mathrm{e}} / \Delta\left(\Delta t_{\mathrm{S}}\right)=0.2161 /{ }^{\circ} \mathrm{C}$. We noticed that at the given temperature difference between indoor and supplied air $\Delta t_{\mathrm{S}}$ the change in temperature of outdoor air $t_{\text {out }}$ practically don't causes the 
change in exergetic output-input ratio $\eta_{e}$. It means that at a certain temperature difference between indoor and supplied air $\Delta t_{\mathrm{S}}$ we can ignore the effect of temperature of outdoor air $t_{\text {out }}$. So the chosen air conditioning system should be preferably used at higher temperature difference between indoor and supplied air, for example at $\Delta t_{\mathrm{S}}=9.0^{\circ} \mathrm{C}$, that will give the opportunity to gain the highest exergetic output-input ratio $\eta_{e}$, which means to gain the most advantageous economical variant of exploitation of the chosen air conditioning system.

The dependence (Fig. 3) has been obtained in a form of analytical equation for temperature difference between indoor and supplied air $\Delta t_{\mathrm{S}}=4.0-9.0^{\circ} \mathrm{C}$ :

$$
\eta_{e}=1.023 \cdot \exp \left(0.102 \cdot \Delta t_{S}\right)
$$

Maximum error of calculations by the equation (11) is $4.3 \%$.

So the exergetic analysis of the implemented central straight flow air conditioning system for operating cleanrooms at a warm period of year, which was performed on innovation mathematical research model created by the authors, provided the opportunity to thoroughly estimate the dependence of exergetic output-input ratio $\eta_{e}$ of this system on temperature difference between indoor and supplied air $\Delta t_{\mathrm{S}}$ at different temperatures of outdoor air $t_{\text {out }}$.

\section{Conclusions}

Innovation mathematical research model of the implemented central straight flow air conditioning system for operating cleanrooms at a warm period of the year was described in this article, which gives opportunity to make computer estimation of its energy efficiency by virtue of exergetic output-input ratio depending on different factors, which have influence on its work. The dependence of exergetic output-input ratio $\eta_{e}$ of this air conditioning system on temperature difference between indoor and supplied air $\Delta t_{\mathrm{S}}$ at various temperatures of outdoor air $t_{\text {out }}$ was presented. It was observed that at the given temperature difference between indoor and supplied air $\Delta t_{\mathrm{S}}$ the change in temperature of outdoor air $t_{\text {out }}$ practically doesn't cause the change in exergetic output-input ratio $\eta_{e}$. It is shown that the chosen air conditioning system should be preferably used at higher temperature difference between indoor and supplied air, for example at $\Delta t_{\mathrm{S}}=9.0^{\circ} \mathrm{C}$, this will give the opportunity to gain the highest exergetic output-input ratio $\eta_{e}$, i.e. to gain the most advantageous economical variant of exploitation of the chosen air conditioning system.

\section{References}

[1] Fedotov A.E. 2003. Cleanrooms. Second edition. - Moscow.: ASINKOM, 2003. - 576 (in Russian).

[2] Hayakava I. 1990. Cleanrooms. Translation from Japanese. - Moscow: Mir. - 456 (in Russian).

[3] Whyte W. 2002. Technology of Cleanrooms. Fundamentals of Design, Testing and Maintenance. - Moscow: Cleanroom. - 304 (in Russian).

[4] Whyte W. 2004. Design of Cleanrooms. Translation from English. - Moscow: Cleanroom. - 360 (in Russian).

[5] GOST ISO 14644-1. Cleanrooms and associated controlled environments. Part 1. Classification of air cleanliness (in Russian).

[6] Sokolov E.Ia. 1981. Energetic Basics of Heat Transformation and Cooling Processes: textbook for higher educational institutions - 2nd edition / E.Ia. Sokolov, V.M. Brodianskii. - Moscow: Energoizdat. - 320 (in Russian).

[7] Shargut Ia. 1968. Exergy / Ia. Shargut, R. Petela. - Moscow: Energiia. - 280 (in Russian).

[8] Exergetic design of engineering systems. 1991: manual / [V.M. Brodianskii, G.P. Verhivker, Ia.Ia. Karchev et al.]; edited by A.A. Dolinskiy, V.M. Brodianskiy; Institute of Technical Thermophysics AN USSR. - Kiev: Nauk. dumka. - 360 (in Russian).

[9] Brodianskii V.M. 1973. Exergetic method of thermodynamical analysis / V.M. Brodianskii. - Moscow: Energiia. - 296 (in Russian).

[10] Ber G.D. 1977. Technical thermodynamics / G.D. Ber. - Moscow: Mir. - 518 (in Russian).

[11] Bogoslovskii V.N. 1985. Air Conditioning and Cool Supply: textbook for higher educational institutions / V.N. Bogoslovskii, O.Ia. Kokorin, L.V. Petrov. - Stroiizdat. - 367 (in Russian).

[12] Prokhorov V.I. 1981. Method of exergy calculation for humid air flow / V.I. Prokhorov, S.M. Shilkloper // Refrigeration engineering (Kholodilnaia tekhnika). - No. 9. - pp. 37-41 (in Russian)

[13] Shilkloper S.M. 1982. Exergetic analysis of systems for microclimate control and energy supply / S.M. Shilkloper, S.I. Zhadin // Construction and architecture (Stroitelstvo i arkhitektura). Vol. 9. - No. 4. - pp. 18-27 (in Russian).

[14] SNiP 2.04.05-86. 1987. Heating, ventilation and conditioning. - Moscow: TsITP Gosstroia SSSR. - 64 (in Russian). 
[15] Iantovskii E.I. 1988. Flows of energy and exergy / E.I. Iantovskii. - Moscow: Nauka. - 144 (in Russian).

[16] Bes T. 1962. Exergy in heating, conditioning and drying processes / T. Bes // Industrial Power Engineering (Energetyka Przemysłowa). - 10, № 11. - pp. 388-392 (in Polish).

[17] Labai Volodymyr. 2000. Exergetic efficiency of main conditioners / Volodymyr Labai, Taras Ivanukh // V Rzeszow-Lviv-Koszyce Scientific Conference „Up-to-date Problems of Civil Engineering and Environmental Engineering”. Proceedings of Rzeszow University of Technology "Civil Engineering and Environmental Engineering”. - V. 32, part 2: Environmental Engineering. - Rzeszow, 25-26 September. - pp. 229-235 (in Ukrainian).

[18] Labay V. 2014. Innovation model for energy effective investigations of air conditioning systems for cleanrooms / V. Labay, D. Harasym // ECONTECHMOD - Lublin-Rzeszow. - Vol. 3, No. 1. - pp. 47-52.

[19] Labai V.I. 2014. Investigation of exergy efficiency for cleanrooms air conditioning systems / V.I. Labay, D.I. Harasym // Refrigeration Engineering and Technology, No. 4 (150). - Odesa: ONAKHT. - 47-53. (in Ukrainian).

[20] Harasym D.I. 2014. Evaluation of cleanrooms air conditioning systems based on the Grassman diagram / D.I. Harasym, V.I. Labay // Civil engineering, material science, mechanical engineering: Proc. Issue No. 76. - Dnipropetrovsk: PHASA. - 95-100 (in Ukrainian).

\title{
Дослідження на інноваційній моделі ексергоефективності системи кондиціювання повітря операційних чистих кімнат
}

\author{
Дмитро Гарасим, Володимир Лабай \\ Національний університет «Львівська політехніка», вул. С. Бандери, 12, м. Львів, 79013, Україна
}

\section{Анотація}

Нині під час експлуатації енерготехнологічних систем (ЕТС), до яких належать системи кондиціювання повітря (СКП), для забезпечення проведення певної технології питання економії паливно-енергетичних ресурсів має першорядне значення. Отже, зменшення затрат енергії, споживаної системами кондиціювання повітря, диктує необхідність їх оптимізації, що найповніше може бути досягнуто на основі ексергетичного аналізу, який враховує не тільки кількість, але й якість затраченої енергії. Розрахунки балансів і різних характеристик ЕТС, зокрема СКП, $з$ врахуванням ексергії дає можливість найпростіше і наглядніше вирішувати безліч наукових і технічних задач. Вони допомагають вилучити часті помилки, які зустрічаються і пов'язані 3 ігноруванням якісного боку перетворень. У статті презентована інноваційна математична дослідницька модель діючої центральної прямотечійної системи кондиціювання повітря для операційних чистих кімнат з метою комп’ютерного оцінювання iï енергетичної ефективності через ексергетичний ККД залежно від різних факторів, що впливають на іiі роботу. Завдяки цій моделі отримано залежність ексергетичного ККД $\eta_{e}$ діючої системи кондиціювання від різниці температур між внутрішнім і припливним повітрям $\Delta t_{n}=t_{b}-t_{n}$.

Ключові слова: ексергетичний баланс; системи кондиціювання повітря; чисті кімнати; ексергетична ефективність. 